\title{
Lidija Bernardić
}

Sveučilište u Zagrebu, Hrvatska

lidijus@gmail.com

\section{Alica u zemlji cenzure: dječji svijet kao mjesto razgovora sa životinjama}

Pregledni rad / review paper

Primljeno / received 5. 5. 2015. Prihvaćeno / accepted 14. 12. 2015.

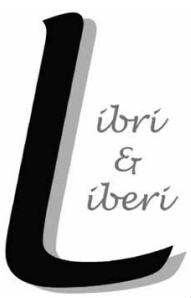

U tekstu se nudi moguće objašnjenje političke zabrane distribuiranja i čitanja djela Aličine pustolovine u Zemlji Čudesa koja je u kineskoj pokrajini Hunan stupila na snagu 1931. godine. Odnos ljudi (posebno vladara) i drugih životinja te odnos komunističke ideologije prema prirodi nude ključ za odgonetavanje političke nepodobnosti toga djela. Nakon tumačenja razloga zbog kojih je „davanje govora životinjama“ subverzivan čin u vrijeme osnaživanja komunističke vladavine u Kini, antropološkim smještanjem djece $\mathrm{u}$,,međuprostor“ između prirode (životinja) i odraslih ljudi i feminističkim iščitavanjem žene kao „,bliže prirodi“" nudi se objašnjenje zašto djevojčica Alica unutar vlastita dječjega svijeta razumije druge životinje.

Ključne riječi: dječji svijet, cenzura, feministička antropologija, govor, komunistička ideologija, životinje

\section{Neprihvatljiva ideja pridavanja govora životinjama}

Vlada kineske provincije Hunan zabranila je 1931. godine čitanje i distribuiranje knjige Aličine pustolovine u u Zemlji Čudesa (Sova 2006: 11-13) jer je u literarnome kolopletu pustolovina jedne djevojčice obostranom uporabom i razumijevanjem govora došlo do simboličkoga izjednačavanja drugih životinja ${ }^{1}$ i ljudi. Alica je, naime, sasvim dobro razumjela životinjski govor. U određenim dijelovima Kine ta je ideja, očigledno, u to vrijeme bila društveno neprihvatljiva.

U tekstu se rabi naziv „druge životinje“ u kontekstu označavanja ostatka životinjskoga svijeta kojemu pripada i čovjek. Danas se često u kulturnoanimalističkoj literaturi, kao i u onoj filozofskoaktivističkoj pojavljuje naziv „,ne-ljudske životinje“, no izbjegavam ga zbog negativne 
Knjige su najčešće zabranjivane, spaljivane i cenzurirane zbog dvaju razloga: ,autori ili djela nisu se prilagodili društvenim očekivanjima svojih cenzora ili su

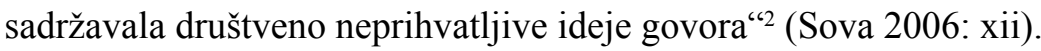

Ako se i zadovoljimo objašnjenjem da je djelo Aličine pustolovine $u$ Zemlji Čudesa ukoričilo upravo taj drugi grijeh - neprihvatljivu ideju govora koji je podaren životinjama - pitanje koje se nameće glasi: zašto životinje u knjigama, štoviše u žanru koji je kasnije prozvan „književnim nonsensom“, 3 ne bi smjele govoriti? Wim Tigges definira književni nonsens kao „žanr pripovjedne književnosti koji dovodi u ravnotežu višestrukost značenja s istodobnim izostankom značenja“ (1988: 47), ističući da književni nonsens karakteriziraju „četiri ključna elementa: neriješena napetost između prisutnosti i odsutnosti značenja, nedostatak emocionalne uključenosti, zaigrano predstavljanje i naglasak na njegovoj jezičnoj naravi koji je jači nego u bilo kojemu drugome tipu književnosti“ (55). Premda nonsens unosi pomutnju postavljajući stvari naopako i „dovodeći ih u svaku vrstu neprirodnih, nemogućih i apsurdnih, ali ne i bolnih ili opasnih kombinacija“, kako kaže Edmund Strachey, nonsens je ipak ,,istinsko djelo imaginacije, dijete genija“ i „cvijet i plod dosjetke i humora“ (1888: 515). Iako se književni nonsens dovodi u vezu s propitivanjem smisla i besmisla, racionalnosti i logičnosti, valja imati na umu da „[književni] nonsens nije besmisao“ (Simoniti 1997: 13). Ono što ima smisla Alici ne mora nužno imati smisla drugim likovima, a vrijedi i obratno: dimenzija prostora i protok vremena, kao i antropomorfizirane životinje samo su neki od naoko besmislenih motiva, ali korisnih i često subverzivnih, jer nonsensni žanr služi za ,ispitivanje valjanosti stanja stvari i razigrano definiranje

definicije. Iako Dunayer (2009), kao i Singer (1998), pa onda i Jurić (2001) argumentiraju da je naziv vrijednosno neutralan (poput naziva „neborac“ ili „,neseksist“) vidljivo je da ti pojmovi ipak imaju svojevrsni pozitivni naboj (i pokušavaju metaforički oboriti nešto negativno), a mogli bismo čak i reći da su paradigmatski idealistički. Singer je, doduše davne 1975., napisao: „'neljudski život' nisam, dakako, upotrijebio u pogrdnom značenju, po kojemu bi 'neljudski život' značio 'život koji nije dostojan čovjeka', 'pasji život' i tome slično" (prema Jurić 2001: 149), no simptomatična je potreba da se na početku rasprave napiše i jedna ovakva svojevrsna apologija u vezi s odabirom naziva. Razlog za to jest metafizika naslijeđa koja, unatoč velikim napredcima $u$ borbi za prava životinja, ali i redefiniranju antropologije same, posebice kako ju vidi Barbara Noske u svojoj knjizi Beyond Boundaries: Humans and Animals (1997), još uvijek podsjeća na naš stav (često izrabljivački i negativan) prema drugim životinjama. O tome je polemizirao Derrida (1990), konkretno na primjeru etnologije, i ustvrdio da nas uvijek prati kompletna metafizika onoga što pokušavamo osporiti. S obzirom na to da se naziv „druge životinje“ rabi jednako često kao i naziv „,ne-ljudske životinje“, odlučila sam se ovdje, kao i u svojim prijašnjim i recentnim radovima, koristiti tom sintagmom.

2 Sve citate prevela je autorica ovoga teksta, osim ako su preuzeti iz postojećega prijevoda navedenoga u popisu literature (op. ur.).

3 Teoretičari i književni povjesničari početke nonsensa nalaze u engleskim malešnicama i djelima viktorijanskih autora Lewisa Carrolla i Edwarda Leara, ali Jean-Jacques Lecercle upozorava da se ne smije odbaciti ni književnopovijesna tradicija nonsensa kao književnoga postupka (1994: 185-186). 
odnosa među kategorijama“" (Khasawneh 2010: 15). Smatram da je upravo ovo razigrano propitivanje granica smisla i besmisla, društvenih normi i odnosa među kategorijama pogodan medij za propitivanje i redefiniranje našega, ljudskoga odnosa s drugim životinjama.

Ako analiziramo odnos kineskoga stanovništva, a posebice nekih njegovih slojeva, prema drugim životinjama i prirodi općenito, možda ćemo pronaći odgovor na pitanje razloga zabrane Carrollove knjige. Konkretan čin zabrane toga naslova proizlazi iz kompleksnoga sustava vrijednosti i hijerarhije života kako su je promovirale osobite ekonomske, kulturološke i političke prilike u tadašnjoj Kini.

\section{Odnos stanovništva Kine prema prirodi i njezinim resursima}

„Opresivna vladavina gora je od tigra.“

Konfucije ${ }^{4}$

Odnos kineskoga naroda i životinja kompleksan je i ambivalentan, a najkorjenitije se mijenja prilikom tektonskih političkih i društveno-ekonomskih mijena. ${ }^{5}$ Kina je početkom 20. stoljeća doživjela politička i ekonomska previranja impozantnih razmjera, ${ }^{6}$ no unatoč opsežnim proučavanjima i analizama političkoekonomskih uzroka i posljedica toga turbulentnoga razdoblja kineske, ali i svjetske povijesti, malo se tko bavio neantropocentričnim i manje vidljivim fenomenima kao što su druge životinje. Turbulentna politička vremena neizbježno su utjecala i na odnos čovjeka i drugih životinja s prirodom, posebice ako uzmemo u obzir kinesku tradiciju koja je političkim i vladinim (carskim) dužnosnicima još u doba drevnih dinastija dodjeljivala važnu ulogu u kontroliranju, umirivanju podanika i općenito posredovanju između prirode i divljih životinja ${ }^{7}$ i podanika.

Takvo shvaćanje životinja kao ne isključivo bioloških jedinki baštini svoje podrijetlo u predcarskoj Kini i predbudističkome razdoblju. Istraživanje tekstualnih

${ }^{4}$ Konfucijev citat preuzet je iz Cogginsove knjige The Tiger and the Pangolin (2003: 65).

5 O toj temi vidjeti u Judith Shapiro (2001) Mao's War Against Nature: Politics and the Environment in Revolutionary China, Chris Coggins (2003) The Tiger and the Pangolin, John Knight (2004) Wildlife in Asia: Cultural Perspectives, Robert B. Marks (2004) Tigers, Rice, Silk, and Silt. Environment and Ecology in Late Imperial South China i Mark Elvin (2006) The Retreat of the Elephants: An Environmental History of China.

${ }^{6}$ Osim inflacije koja ju je pogodila 1929. godine i dvaju ratova s Japanom koji su uslijedili nekoliko godina poslije, nemoguće je zaboraviti i građanski rat koji je Kinu podijelio praktički na dvije „države“ - onu pod vlašću nacionalista (Koumintanga) i onu kojom su upravljali komunisti (Komunistička partija Kine) te kulturnu revoluciju koja je započela 1966. godine. To je razdoblje obilježio kaos unutarnjih turbulencija i nemira, ali i drastičan zaokret u ideologiji odnosa prema prirodi, divljim i domaćim životinjama, ,korisnim i štetnim“ biljnim i životinjskim vrstama i slično.

7 Više o toj temi vidjeti u knjizi Chrisa Cogginsa The Tiger and the Pangolin (2003). 
zapisa iz predcarskoga ${ }^{8}$ i ranocarskoga razdoblja ${ }^{9}$ iz današnje je perspektive zanimljivo jer (Sterckx 2004: 15):

[...] percepcija svijeta iz vremena klasične Kine nije inzistirala na jasnim kategoričkim ni ontološkim granicama između životinja, ljudskih bića i drugih bića kao što su duhovi i duše. Posljedično, demarkacija ljudskoga i životinjskoga područja nije se percipirala kao trajna ili stalna, a fiksnost vrsta nije bila samorazumljiva.

Kako bismo što bolje ilustrirali taj dio drevne kineske kulture, poslužimo se etimologijom riječi ,životinja“. U predbudističkome razdoblju u kineskome jeziku nije postojala riječ za životinju, barem ne onakvu kakvu poznajemo danas.

Riječ „životinja“ u hrvatskome jeziku ima praslavenski korijen *životıni $\simeq$ v. živ, život. ${ }^{10}$ Engleskoj i hrvatskoj riječi zajednička je Platonova ideja „zoona“

8 Zapisi o drugim životinjama u Kini datiraju u davnu prošlost. Natpisi na kostima koje su služile za čaranje tijekom perioda dinastije Shang (1200. g. pr. n. e. - 1045. g. pr. n. e.) sadrže mnoge podatke o drugim životinjama, a slične su se informacije zapisivale i tijekom dinastija Zhou (1045. g. pr. n. e. -221 . g. pr. n. e.) i ranocarskoga razdoblja (221. g. pr. n. e. - 9. g. n. e.). Najstarija kineska zbirka pjesama, Shijing [Ode], sadrži pjesme nastale između 10. i 7. st. pr. n. e. i također je izvor bogat motivima drugih životinja. Katalog carske knjižnice u Changu koji je sastavio Liu Xin (46. g. pr. n. e. - 23. g. n. e.), a koji se čuva u Hanshuu, sadrži zapise o fizionomiji drugih životinja, pecanju i posvećenju kornjača (v. Sterckx 2005). Rasprave o glazbi u Liji (Yueji) i Shiji (Yueshu) problematiziraju odnos drugih životinja s glasanjem i njihovom prijemčivosti za raspoznavanje melodije. U tim se raspravama zaključuje da druge životinje poznaju fenomen zvuka (zhi sheng), ali ne i tonove (bu zhi yin). Zbog svega toga, zaključuje se u raspravama, zvukove u glazbu mogu preobraziti (kultivirati) samo mudraci ili gospoda (v. Sterckx 2000). Djelo Dong Zhongshua (179. g. pr. n. e. - 104. g. pr. n. e.) Chunqiu fanlu [Raskošna rosa proljeća i jeseni] već je mnogo konkretnije po pitanju odnosa vladara i drugih životinja. Citat „ne želi mudrac tumačiti razlike između vrsta ptica i zvijeri (shuo niaoshou zhi lei). Mudrac želi tumačiti dobronamjernost i pravednost i vladati njima [...]“ (v. Sterckx 2002) svjedoči o tome da ranokineska filozofija stavlja naglasak na tumačenje etičkih životnih načela umjesto na definiranje taksonomskih razlika. Za nas je još i važniji tekst autora Wang Chonga (27. g. n. e. - otprilike 100. g. n. e.), Lunheng jiaoshi [Usporedba i razjašnjavanje diskursa u ravnoteži], koji sadrži nekoliko velikih dijelova i zasebnih poglavlja o drugim životinjama: „Raspravu o insektima“, „Laži o zmajevima“ i, možda najvažnije za našu temu, „Susrete s tigrovima“. U potonjemu poglavlju Wang Chong pokušava opovrgnuti poveznicu između napada tigrova na ljude čija je vladavina loša iako teroriziranja tigrova vidi kao nasumične epizode, tvrdeći da tigrovi u naselja ulaze čim se vladajući iskvare i prestanu mariti za ljude (v. Sterckx 2002).

9 Ranocarsko razdoblje otprilike obuhvaća razdoblje od 5. st. pr. n. e. do sredine 2. st. n. e. Za iscrpan pregled kulturne povijesti drugih životinja u Kini iz toga razdoblja vidjeti radove Roela Sterckxa, profesora kineske povijesti i kulture na Sveučilištu u Cambridgeu, a posebice knjigu The Animal and the Deamon in Early China (2002) koja ranokineske stavove prema drugim životinjama rabi kao ,prozor" u svijet kineske filozofije i poimanja svijeta, zatim tekstove „Transfroming the Beast: Animals and Music in Early China“ (2000), „Animal Classification in Ancient China“ (2005) i „Searching for Spirit: Shen and Sacrifice in Warring States and Han Philosophy and Ritual“(2007). Oslanjamo se pretežno na njegova djela jer se tom, još uvijek neistraženom, temom bavio iscrpno i u svojim je tekstovima analizirao, popisao i na engleski preveo većinu tekstova napisanih na kineskome koji su relevantni za našu temu.

${ }^{10}$ Petar Skok navodi etimologiju pridjeva žîv, živa na sljedeći način: „ie., balto-slav., sveslav., i preslav. pridjev obrazovan s pomoću sufiksa - u্ f. žilva, [...] sr. r. žívo n (Hvar) 'životinja, magarac ili mazga' = žîvo, gen. ž́viva ili žîvōga (Bosna, Piva-Drobnjak) 'blago, stoka'“ (1988: 1107). Od pridjeva žív onda dolazi „,[b]altoslav. i praslav. 
koja pretpostavlja opoziciju živo - neživo kao razlikovnu kategoriju. Sterckx (2005) upozorava da se koncept koji uključuje sve živo (ljude i druge životinje), a isključuje anorgansku materiju, minerale, biljke, gljive i slične organizme, ne podudara u potpunosti s kineskim ekvivalentima za životinju kao što su $w u$ ('stvari', 'stvorenja', 'fenomeni'), shou ('divlje zvijeri'), qin ('divlje ptice/životinje'), chong ('kukci', 'beskralješnjaci') pa čak ni sa suvremenim generičkim nazivom „dongwu“ koji označava životinje dongwu ('biće koje se kreće').

Generičke definicije, dakle, rijetke su, pa se s pravom možemo zapitati kako se onda klasificiraju i određuju živa bića. Nastavimo dalje sa Sterckxom koji navodi jedan relativno kasni ulomak sačuvan u tekstu Liezi, a u kojemu je čovjek definiran kao biće „s kosturom visokim dva metra, kosom na glavi i zubima u ustima, a što stoji uspravno dok trči“, dok su ptice i zvijeri opisane kao bića „,s krilima sa strane ili rogovima na glavi, razmaknutim zubima i ispruženim kandžama, a lete prema gore ili hodaju pognuta prema dolje“ (2005: 29).

Još je znakovitije da je (Sterckx 2004: 15):

[...] dihotomija između „,moralne“ $\mathrm{i}$,prirodne“ životinje rijetko artikulirana u ranoj Kini [...]. Životinjski je svijet, na nekoliko načina, pružao normativne modele i smjernice za upravljanje ljudskim društvom. Više od ikoje druge kategorije u prirodnome svijetu, životinje su funkcionirale kao prizma u kojoj su se preklapale priroda i ljudsko društveno uređenje.

Iz navedenoga postaje jasnije da je poprilično zahtjevno istraživati odnos stanovništva Kine iz toga ranocarskoga razdoblja jer je u zapisima očigledno da ne postoji ,aporija o životinjskome svijetu kao zasebnome području znanja“ (Sterckx 2004: 15). Znanje o drugim životinjama i prirodnome svijetu bilo je dijelom istoga epistemološkoga sustava, što je bitno napomenuti u kontekstu promjena koje će se dogoditi početkom 20. stoljeća.

U tome ranome razdoblju vidljiva je snažna simbolička veza između vladara i divljih životinja jer su životinje predstavljale kategorije u neprekidnoj dinamici promjene kojima je vladar trebao ovladati. To je bilo (isto):

[...] posebno pravo mudraca ili vladara kralja. Dok je nametao svoj društveno-politički autoritet lovom na divlje životinje i simboličkim ovladavanjem onim što je pripadalo životinjama, vladar je morao motriti ravnotežu između ljudskoga i životinjskoga svijeta povezujući obrasce ponašanja iz obližnje divljine s djelovanjem ljudske vladavine.

Aporija koja danas postoji u suvremenome svijetu upravo zbog sučeljavanja dviju različitih ideja: da je čovjek dio prirode, ali i superiorniji od nje, nije postojala u drevnoj Kini. Iako su (Sterckx 2004: 16):

izvedenica [od živъ] na -ot žìvot, gen. živòta m., [...] s pridjevom na -bn>-an žìvotan. Odatle na -ina živòtina = na -yǹi živòtinja (Dubrovnik) [...], s pridjevima na -in živòtinjin, na -bsk živòtinjskī $\mathrm{s}$ apstraktumom na -stvo životínjstvo $\mathrm{n}$." (isto). 
[...] rani kineski tekstovi izlagali različite stavove o tome kako ljudska bića prilagoditi životinjama, asimilirati ili pak odvojiti od životinja, univerzalno prihvaćena teorija koja bi slavila superiornu ljudsku dominaciju nad životinjama nije postojala. Rani kineski mislioci nisu ni razvili filozofije prirode koje bi pokušale objasniti nadmoć ljudske vrste zbog fizičkih ili protobioloških pretpostavki.

Osim što nije postojao ontološki jaz između čovjeka, prirode i drugih životinja niti je postojala ideja ljudske nadmoći u odnosu na ostatak živoga svijeta, rana kineska tradicija njegovala je ,ideju da se divlje životinje mogu transformirati u kulturne subjekte pod utjecajem moralne vladavine“" (Sterckx 2004: 17), što je važan kulturološki naglasak koji nam pomaže shvatiti podrijetlo i uzrok političke zabrane djela Aličine pustolovine u Zemlji Čudesa.

Povijest odnosa prema prirodi i njezinim resursima u Kini varirala je stoljećima odnosno tisućljećima. Coggins navodi „,̌etiri stadija razvoja eksploatiranja prirodnih resursa i percepcije okoliša od kasnocarske ere (1368. - 1911.)“ (2003: 20), a Mark Elvin (2006) donosi detaljniji prikaz koji seže daleko u povijest kineske civilizacije, točnije tri tisućljeća unatrag, otkad datiraju najstariji zapisi. Koristan prikaz donosi i Marks u knjizi Tigers, Rice, Silk, and Silt (2004). U recentnijim tekstovima, međutim, razni autori pišu upravo o Kulturnoj revoluciji i razdoblju jačanja komunističke ideologije kao onome razdoblju koje je najsnažnije negativno utjecalo na okoliš, bioraznolikost i eksploatiranje prirodnih resursa uopće. Tako o nepovoljnome, eksploatatorskome i ekološki pogubnome utjecaju Kulturne revolucije na kineske prirodne resurse pišu, primjerice, Judith Shapiro u knjizi Mao's War Against Nature: Politics and the Environment in Revolutionary China (2001), već spomenuti Chris Coggins (2003), Samuel Turvey u knjizi Witness to Extinction: How We Failed to Save the Yangtze River Dolphin (2009), Mark Elvin u tekstu „The Environmental Impasse of the Late Imperial China“ (2010), a također i Daisy Yan Du koja tvrdi da se u kontekstu animiranoga filma ,kineska Kulturna revolucija može redefinirati kao desetljeće odsutnih životinja“ (2016). Upravo se u tome vremenu događa i zabrana čitanja i distribuiranja djela Aličine pustolovine $u$ Zemlji Čudesa. Naravno da ne treba zanemariti da je sličnih scenarija bilo i ranije. Detaljan pregled ekoloških promjena koje su se događale od naseljavanja Lignana za vrijeme dinastija Han i Qin do početka 20. stoljeća nudi Marks u spomenutoj knjizi (2004), no bitno je napomenuti da uz antropogene učinke degradiranja okoliša (jer i on tvrdi da je prije početka naseljavanja Lignana taj dio Kine vrvio životinjskim i biljnim vrstama, što se promijenilo do početka 20. stoljeća) upozorava i na prirodne uzroke koji su se događali mimo utjecaja čovjeka (v. posebno treće poglavlje, u prijevodu naslovljeno „Poljoprivreda je temelj“‘). Od 1400. do 1900. godine, primjerice, ,ekonomski [je] rast u kasnocarskoj Kini [...] već uvelike u 
mnogim aspektima nalikovao onome u zapadnim zemljama u svitanje industrijske revolucije“" (Elvin 2006: 82), a obilježilo ga je također eksploatiranje prirodnih resursa i tomu odgovarajući odnos prema drugim živim bićima. Iako nitko ne osporava da je takvih oscilacija u suživotu kineskoga stanovništva i prirode tijekom povijesti bilo mnogo, Kulturna revolucija i komunistička partija dovele su prakse eksploatiranja i pokoravanja prirode na sasvim novu razinu, o čemu će više govora biti kasnije.

Naznake poboljšanja bile su vidljive tek krajem 20. stoljeća: tek je 1988. godine usvojen prvi zakon o zaštiti divljih životinja i prirode kojim je utvrđeno da je ,cijela divljina vlasništvo naroda i da ju se mora pažljivo štititi, aktivno širiti, istraživati i racionalno iskorištavati““ (Coggins 2003: 23).

Unatoč neprekidnim povijesnim oscilacijama u odnosu stanovnika Kine s ostatkom živoga svijeta, moguće je ipak konstatirati prisutnost neprekidnoga interesa za druge životinje, a posebice za neke specifične i važne vrste koje su snažno utjecale na stvaranje lokalnih i nacionalnih identiteta. Kineski tigar jedna je od takvih vrsta „karizmatične faune“, a o tome su pojmu pisali Zdenko Zeman i Marija Geiger (2007). Iako se u njihovu članku karizmatična fauna uže povezuje sa stvaranjem lokalnih identiteta unutar zajednica koje su bliže i neposrednije u odnosu i doticaju s prirodom koja ih okružuje, primjer kineskoga tigra pokazuje mogućnost podizanja određene vrste na razinu nacionalnoga simbola, predmeta, odnosno pojma od nacionalnoga biopolitičkoga značaja (usp. Coggins 2003).

O povlaštenome statusu kineskoga tigra kao životinjske vrste svjedoče brojni tekstovi, ali i projekti zaštite okoliša s ciljem njegova očuvanja. Južnokineski tigar (Panthera tigris amoyensis) vrsta je pod posebnom zaštitom Narodne Republike Kine $\mathrm{i}$ to ne bez razloga. Kineski tigar zauzima posebno mjesto $\mathrm{u}$ kineskoj kozmologiji: ${ }^{11}$ vjeruje se da ima posebne „,nadnaravne i medicinske moći, a u suživotu s ljudima poprimio je i antropomorfne osobine inteligentnoga bića“ (Coggins 2003: 1-2). Kao što je u zapadnjačkoj tradiciji lav kralj životinja, tako je i tigar u kineskoj tradiciji bio poznat kao „kralj stotinu zvijeri (baishouzhiwang)“ (84). Huhui [Priručnik o tigrovima], zbirka tekstova o tigru iz 16. stoljeća, svjedoči o ambivalentnome stavu koji su ljudi gajili prema tigrovima. Osim što se ,smatralo da mogu razmišljati racionalno, ponekad su čak smatrani odgovornima za svoja nedjela“ (isto). Upravo je južnokineski tigar endemska podvrsta koja je najrjeđa

${ }^{11}$ Marks tigrove i slonove naziva „vrstama zvijezdama“ (star species), tj. vrstama koje su se nalazile na vrhu hranidbenoga lanca (zajedno s ljudima), za čiji je opstanak uvijek bio potreban velik teritorij i koje su doživjele gotovo potpuno istrjebljenje zbog ljudskoga djelovanja: slonovi su istrjebljivani puškama (trgovina bjelokosti), a tigrovi ,u holokaustu tijekom krčenja šuma na području Lignana““ (2004: 331). To gotovo potpuno uništenje kineskoga tigra i Marks vidi kao „važan dio kineske povijesti“ (336). O još jednoj karizmatičnoj vrsti, mravojedu, pisao je Coggins (2003). 
na svijetu, a sa svega nekoliko desetaka jedinki preživjelih u divljini postala je najsnažnijim i najpoznatijim simbolom prirodnoga bogatstva i nasljeđa te zemlje. ${ }^{12}$

Zbog važnosti tigra kao vrste za stvaranje lokalnih identiteta, ali i nacionalnoga identiteta, odabir je kineskoga tigra paradigmatski primjer odnosa stanovnika Kine prema prirodi i drugim životinjskim vrstama. Njegova važna uloga u političkome folkloru Kine, o kojoj će više govora biti u sljedećem dijelu teksta, dodatni je razlog odabira upravo te životinjske vrste kao primjera za daljnje razmatranje.

Nadalje, valja se prisjetiti da je i Cerigradska Mačka u Aličinim pustolovinama u Zemlji Čudesa (Carroll 2004) također bila velika, prugasta mačka - nalik tigru.

\section{Uloga vladara kao medijatora između čovjeka i prirode nasuprot ulozi tigra kao medijatora između nebesa i vladara}

U vezi sa zabranom čitanja i distribuiranja Alice koju je proglasio politički dužnosnik, general Ho Chien, važno je napomenuti da su vladari i vladajući (carski) dužnosnici tisućama godina imali osobit odnos s određenim životinjskim vrstama koje su služile kao svojevrsni korektiv i indikator pravičnosti aktualnih vladara i njihove vladavine.

Priča o Song Junu (Sterckx 2002), otprilike iz polovice prvoga stoljeća, dobro ilustrira tu međuovisnost vladajućih s drugim životinjama, a posebice s tigrovima. Song Jun bio je poznat po kritičkome stavu prema praksi šamanizma i slovio je za oštroga protivnika praznovjerja. Dobio je zadaću riješiti probleme u pokrajini Jiujiang desetkovanoj napadima tigrova na ljude i stoku. Zbog učestalih napada vladajući su bili primorani povisiti poreze, a seljaci raditi još više i mukotrpnije. Po dolasku u iscrpljenu i osiromašenu pokrajinu napisao je edikt u kojemu je apelirao na vladajuće molbom da prestanu s lovom na tigrove u kojemu su uživali i da se usredotoče na promicanje lojalnosti i dobrote, ukinu visoke poreze i ublaže siromaštvo. Legenda kaže da su se nakon primjene toga naputka sa Songom Junom povukli i tigrovi. Mudra vladavina, dakle, ključ je mirna suživota ljudi i drugih životinja, a pojačani napadi divljih životinja i njihov ulazak u ljudska naselja pokazatelj su toga da vladajući ne obavljaju dobro posao, zbog čega ispašta čitava zajednica.

Dobri odnosi s prirodom, a posebice $\mathrm{s}$ pojedinim životinjskim vrstama, podanicima, značili su da su njihovi vladari, koji su izravno bili odgovorni nebesima koja su ih i ustoličila, bili dobri i da su donosili blagostanje svojoj zemlji. Tigar se razumijevao na sličan način, barem do (Coggins 2003: 12):

${ }^{12} \mathrm{O}$ pokušajima da se očuvaju sve podvrste tigra, a među njima i kineski tigar, pisali su Ronald L. Tilson i Ulysses Seal u knjizi Tigers of the World (1987), posebno u poglavljima naslovljenima (u hrvatskome prijevodu) „Dostupnost staništa i perspektive za tigrove u Kini“, „Stanje i problemi zatočenih tigrova u Kini“ i ,Tigrovi u divljini: biopolitički izazovi“. 
[...] duboko u dvadeseto stoljeće [do kada ga] se smatralo predstavnikom nebesa koji je mogao donijeti pravdu obespravljenima, pomoć pravednima u vrijeme nevolje ili nametnuti vladavinu terora zlikovcima. Dobri odnosi između ljudi i tigrova ovisili su dakle o tome koliko se dobro upravljalo zemljom - o mandatu Nebesa (tianming) i o stupnju sklada u zemaljskome carstvu.

O povezanosti tigra s nebesima, kao i o idealu vladara kao pobožne i moralne osobe svjedoče zapisi iz lokalnih glasila (novina) koji datiraju iz 17. i 18. stoljeća. Primjerice, tekst iz pokrajine Pinghe iz sedme godine Ming Chongzhena iz 1634. donosi informacije o brojnim i krvavim napadima tigrova na ljude čemu je na kraj stala molitva magistrata koji je planinske duhove zamolio za milost (usp. Coggins 2003: 80-85).

Susreti čovjeka i životinja u Kini bilježeni su stoljećima zbog njihove važnosti za politiku vladajućih. Odnos štete i koristi koje su, primjerice, populacije tigrova nanosile lokalnom stanovništvu, zahvaljujući lokalnim glasilima ${ }^{13}$ koja su objavljivala vijesti o napadima tigrova na ljude, moguće je sustavno pratiti „na nacionalnoj razini na početku vladavine dinastije Ming, [od] 1368. godine“ (Coggins 2003: 70).

Bilješke i vijesti koje su se objavljivale u lokalnim glasilima četiriju jugoistočnih provincija (Fujian, Jiangxi, Hunan i Guandong), ,jedinstvena su kronološka zbirka interakcije između ljudi i drugih životinja kojoj na čitavome svijetu nema premca“, ustvrdio je Coggins (2003: 55). Za vijesti o susretima čovjeka s tigrovima u takvim glasilima bila je rezervirana zasebna rubrika ,,shouzai“"14 što bi se moglo prevesti kao 'katastrofe uzrokovane djelovanjem životinja' (71).

Od početka prvoga stoljeća, dakle od samoga početka vladavine dinastije Han, datira djelo Lunheng jiaoshi [Usporedba i razjašnjavanje diskursa u ravnoteži] filozofa Wang Chonga koji je čitavo poglavlje pod nazivom „Zao hu“ [Susreti s tigrovima] posvetio napadima tigrova. U njemu raspravlja o razlozima ulaska tigrova u ljudska naselja. Iako isprva negira povezanost nadnaravnih sila s tim događajima, zaključuje da su takve epizode ipak posljedica „,degradacije aktualne vladavine“" (Sterckx 2002: 141).

Treba navesti i vjerovanje u to da nakon susreta s tigrovima slijedi propast grada, prema proročanstvu koje je izrekao Zhou Wuyang (Struve 1993: 92).

Takva odluka carskih dinastija da se dokumentiraju sva događanja povezana sa štetom koju su životinje načinile ljudima svjedoči o važnosti koja je pridavana suživotu ljudi s drugim životinjama, ali i o važnosti dijela kineske folklorne tradicije , tj. ,prakse i vjerovanja koje su povezivale vladare i druge osobe u vlasti

${ }^{13}$ Jedna od najvećih zbirki arhivskoga materijala iz lokalnih glasila čuva se na Sveučilištu Fujian u zbirci drevnih knjiga, a upravo je ta zbirka poslužila Cogginsu prilikom istraživanja za knjigu The Tiger and the Pangolin (2003).

${ }^{14}$ Coggins taj termin prevodi engleskom sintagmom 'bestial disasters' (2003: 71). 
s religijskim moćima“ (Coggins 2003: 82). Prema vjerovanju kineskoga podanika vladari su uvijek imali vezu s nebesima. Ta posrednička uloga osiguravala je dobar odnos s prirodom za vladavine benevolentna vladara, ali i kaos u slučaju nepravedne, tlačiteljske ili izrabljivačke vlasti. Može se, dakle, zaključiti da su vladajući imali odgovornu ulogu u kontroliranju prirode, o čemu svjedoči i statistika koja kaže da su se morali umiješati u rješavanje ,jednoga od deset zabilježenih slučajeva“ (isto).

Postojala je dakle ,stvarna povezanost između moralnoga djelovanja predstavnika vlasti [...] i njihove sposobnosti da zaustave pustošenja najopasnijih zvijeri koje postoje u prirodi“ (Coggins 2003: 83). Na taj bi način opravdali svoju vladajuću poziciju, ali ju i dodatno utvrdili i osigurali jer ako je šteta uzrokovanih divljim životinjama i prirodnim nepogodama bilo malo, bio je to pozitivan znak s nebesa da je vladavina pravedna i legitimna.

No, takve magijsko-religijske tradicije, kao i odnos vladajućih prema prirodi, promijenile su se s vremenom, a tome je posebno pridonio i prodor zapadnjaka u Kinu, posebice krajem 19. i početkom 20. stoljeća. Upravo u to vrijeme dolazi do sve snažnije fluktuacije prirodnih znanstvenika sa Zapada koji sakupljaju biljne i životinjske uzorke i primjerke biljnih i životinjskih vrsta za znanstvena istraživanja (primjerice Pere Armand Davids, Roy Chapman Andrews i William Lord Smith), a s fluktuacijom ljudi uvijek dolazi i do izmjene kulturnih vrijednosti i tehnologije. ${ }^{15}$ Stoga na prijelazu u 20. stoljeće dolazi do mijene u odnosu domaćega stanovništva prema autohtonim biljnim i životinjskim vrstama: od nadnaravnih bića postali su tržišno vrijedna roba i objekti znanstvenoga proučavanja. Vrhunac toga objektiviziranja i utilitarističkoga pogleda na prirodu i njezine resurse slijedit će u razdoblju Mao Ce Tungove vladavine, a posebice za Velikoga skoka naprijed.

Jačanjem komunističke političke ideologije i prakse i Mao Ce Tungovim političkim usponom (Coggins 2003: 25):

[...] politika upravljanja divljim životinjama Kineske komunističke stranke bila je, najblaže rečeno, utilitaristička, ali češće otvoreno neprijateljska i agresivna. Državni rukovoditelji svih razina organizirali su kampanje istrjebljivanja životinja koje su napadale stoku, jele usjeve, širile bolesti ili ih se načelno percipiralo kao štetočine.

Uz ideju Velikoga skoka naprijed prirodi (točnije divljini) objavljen je ideološki rat u kojemu su sudjelovale vlasti, ali i seljaci koji su ,postali križari u bezbrojnim 'bitkama' protiv divljine, nekultivirane zemlje i nenaseljenoga područja“ (Coggins 2003: 95).

Potez generala Ho Chiena ${ }^{16}$ nije nelogičan niti neobičan ako u kontekst uvedemo političku ideologiju koja je u Kini 30-ih godina 20. stoljeća počela jačati.

${ }^{15}$ Više o tim promjenama vidjeti u Shapiro (2001) i Coggins (2003).

${ }^{16}$ General Ho Chien bio je pripadnik Kuomitanga, a ne Komunističke stranke Kine, KSK-a, no smatram da je njegov čin u skladu s komunističkom ideologijom koja će kasnije uvelike promijeniti 
Zajedno s političkom idejom tehnološkoga, ekonomskoga i kulturnoga napretka u ruralnim se sredinama i krajevima počeo širiti svjetonazor „pokoravanja prirode“, tj. eksploatacije životinja i uništavanje biotopa, ali i flore i faune koja nije služila velikom planu napretka i ekstenzivne proizvodnje. Šume su stradavale nauštrb polja riže i drugih žitarica, a divlje životinje nauštrb uzgoja domaćih jer je ekonomska isplativost, osnaživanje izvoza i industrije bilo prioritet ne samo političkih vođa, nego i čitava stanovništva.

Nije teško zamisliti da bi u to vrijeme književni lik koji razgovara sa životinjama predstavljao nepoželjan pedagoški i ideološki uzor djeci, što je dovelo do zabrane Carrollova romana i uskraćivanja toga djela potencijalnim čitateljima, što je učinio baš jedan od suvremenih „vladara“, general Ho Chien, koji je iskoristio svoju tradicijsku ulogu medijatora između drugih životinja i ljudi i zabranio čitanje, tiskanje i distribuciju Aličinih pustolovina u Zemlji Čudesa.

U prilog ovoj tezi ide i već spomenuti fenomen nestajanja životinja u kineskim animiranim filmovima iz toga vremena (Yan Du 2012, 2016) koji također koincidira s razdobljem Kulturne revolucije. Tijekom sedamnaest godina (1949. - 1966.) prije Kulturne revolucije animirani su filmovi obilovali antropomorfnim životinjama. Primjerice, prvi međunarodno priznati animirani film Zašto je vrana crna (1956) braće Wan ${ }^{17}$ priča poučnu priču o vrani koja nepripremljena za zimu odluči zapaliti vatru u šumi na kojoj zapali pera na repu. Uspjeh filma na Venecijanskome filmskome festivalu donio je svjetsko priznanje Šangajskome studiju za filmsku animaciju, SAFS-u ${ }^{18} \mathrm{u}$ kojemu je film nastao, ali i patronat Mao Ce Tungove vlade. Sljedeći animirani film iz istoga studija i istoga autorstva, braće Wan, prikazuje praščića koji jede lubenicu. Film Praščić jede lubenicu ${ }^{19}$ (1958) uzima motiv svinje kako bi prikazao narodnu priču o junaku iz jednoga od četiriju najslavnijih romana kineske književnosti, Putovanja na Zapad, Zhu Bajieu. I u filmu Pametni pačić iz 1960. godine glavni je lik životinja.

odnos kineskoga stanovništva prema prirodi i u nekim segmentima (sječi šuma, dovođenju određenih životinjskih vrsta do ruba istrjebljenja i sl.) dovesti je i do ruba ekološke propasti. Pod njegovom je paskom stasao i Peng Dehuan, jedan od eminentnijih komunističkih vođa i ministar obrane Kine od 1954. do 1959. godine. Iako se u prvim fazama provođenja Kulturne revolucije i Velikoga skoka naprijed nije suprotstavljao Mao Ce Tungu, to se promijenilo kad su posljedice provođenja komunističke politike postale očite (nestašice hrane, glad, nezadovoljstvo seljaka redistribucijom dobara i radne snage). Tada je počeo otvoreno kritizirati Mao Ce Tungovu politiku.

${ }^{17}$ Detaljniji prikaz utjecaja braće Wan na kineski animirani film može se naći u The Oxford Handbook of Chinese Cinemas (Rojas i Chow 2013) kao i u anonimnim tekstovima „History of Chinese Animation“ (World Public Library 2015) i „Chinese Animation Shows World it Has Midas Touch“ (China Culture 2008). Usp. također Chinese Animation: A History and Filmography, 1922-2012 (Giesen 2015).

${ }^{18}$ Kineski naziv studija glasi Shàng Hăi Měi Shù Diàn Yǐng Zhì Piān Chăng, a na engleski se prevodi kao Shanghai Animation Film Studio, otuda i kratica SAFS.

${ }^{19}$ Film se na anglofonim područjima naziva također i Mr. Pig Eats Watermelon [Gospodin Prasac jede lubenicu] ili Zhu Bajie Eats Watermelon [Zhu Bajie jede lubenicu]. 
No, vrhuncem prevlasti komunističke ideologije i Mao Ce Tungove vladavine animirani film postao je tek dodatnom platformom za osmišljavanje i plasiranje propagande, štoviše to je postala jedina legitimna svrha postojanja studija za filmsku animaciju. U svim spomenutim izvorima o razdoblju Kulturne revolucije piše se kao o vremenskome intervalu unutar kojega je zamah kineske animacije usporen, iako se ona do tada uspješno nosila sa svjetskim trendovima u tome području filmske industrije. ${ }^{20}$

S obzirom na to da je animiranim filmovima sredinom 1960-ih dominiralo ljudsko djelovanje u stilu revolucionarnoga realizma, životinje su sustavno nestajale iz filmova, s ekrana i platna, sve do kasnih 1970-ih zbog propagandnoga tona kojim su se veličala ljudska dostignuća i vrline. U tome periodu nastali su filmovi kao što su Maleni trubač (1973), koji govori o dječaku koji je postao slavnim čuvarom Crvene armije, Malena komunistička gerilska divizija ${ }^{21}$ (1973) i Maleni stražar s Istočnoga kineskoga mora. Ti filmovi nisu, kao prijašnji, uvodili animalističke motive, barem ne u jednakome kontekstu. Ranija animacija isprepletena je motivima drugih životinja koje, često antropomorfizirane, gledateljima prenose određene moralne poruke i pouke. Ideologija Kulturne revolucije ne može se okarakterizirati kao edukativna i poučna nego upravo suprotno - kao dogmatska i isključiva jer $u$ plasiranju propagandnih ideja gledatelju ne nudi prostor za propitivanje konzumiranoga.

\section{Mala literarna buntovnica: zašto djevojčica ipak razgovara sa životinjama?}

„[...] životinje su činile prvi krug onoga što je okruživalo čovjeka [...]. Bile su s čovjekom u središtu njegova svijeta [...]. No pretpostaviti da su u ljudsku imaginaciju najprije ušle kao meso i koža ili rogovlje znači projicirati devetnaestostoljetni stav unatrag na tisućljeća. Životinje su prvo ušle u imaginaciju kao glasnici i kao obećanja."

John Berger (2009: 12)

Stručna pedagoška, psihološka, antropološka, etološka, veterinarska i ina literatura prepuna je primjera u kojima se, istraživanja i generalizacije radi, djeca

$\overline{{ }^{20}}$ To je vrijeme kada su kineski animirani filmovi osvojili mnoge međunarodne nagrade. Primjerice, film Nevolje u nebesima iz 1960. osvojio je nagradu Londonskoga međunarodnoga filmskog festivala, a nagrađivani su i drugi filmovi, npr. Paun leti jugoistočno, Rotkvica se vraća, Zlatna školjka (China Culture 2008).

${ }^{21} \mathrm{Na}$ engleskome se jeziku najčešće upotrebljava naziv Little 8th Route Army, a s obzirom na to da je „Route Army“ prijevod kineske sintagme kojom se označavala posebna jedinica komunističke gerilske vojske koja je djelovala u na sjeveru Kine, hrvatski je prijevod naslova ovdje prilagođen tomu kontekstu. 
na konceptualnoj razini često povezuju s prirodom i drugim životinjama. ${ }^{22}$ Oni svjedoče o fenomenu poimanja djece u društvenim i u prirodnim znanostima i pripadajućim im diskursima kao ne još potpuno razvijenih ljudi te zbog toga bližih prirodi i drugim životinjama. Stoga u strukturalističkoj maniri umjesto „kulinarskoga trokuta“ kako ga je Leach (1982: 36) iznio u svojoj knjizi o LeviStraussu, nudim ovaj slični koji se tiče odnosa čovjeka i prirode (uvjetno rečeno: dviju binarnih opozicija) i međustupnja: djeteta koje pripada objema domenama.

Djeca su od najranije dobi okružena prikazima drugih životinja (u slikovnicama, knjigama, animiranim filmovima), kao i igračkama koje su najčešće antropomorfizirani modeli drugih životinja (odjeveni u ljudsku odjeću, bipedalni, tj. osovljeni na dvije noge, a nerijetko i našminkani). Odrasle osobe često se služe posebno modificiranim jezikom ${ }^{23}$ kada se obraćaju djeci (modificirana prozodija, viša intonacija, sporiji govor s više ponavljanja, češćim i duljim pauzama i sl.), a sličan obrazac komunikacije odrasle osobe rabe i u obraćanju kućnim ljubimcima ili osobama kojima se rugaju.

Takva poimanja djece i dječjega svijeta suprotstavljena su poimanju odraslih osoba kao civiliziranijih, bližih onomu kulturnomu, kao entitetima koji su se „razveli od prirode“ te su „racionalni, logični i znanstveni““ (Cosslett 2002: 2).

Slična se „napetost“ suprotnosti može pronaći i u dječjoj književnosti (usp. Cosslett 2002): s jedne strane priče za djecu didaktičko su sredstvo koje im predstavlja i približava svijet odraslih, a s druge strane ta literatura slavi upravo ono dječje, naglašavajući dječji svijet kao nešto posebno i drukčije. I Perry Nodelman (2004) na primjeru slikovnica pokazuje da dječja književnost katkada djecu predstavlja kao blisku i sličnu životinjama, za razliku od odgovornih odraslih likova.

Ideja da su djeca ,bliža prirodi“ nudi nam priliku za drukčije iščitavanje Alice: djevojčica razumije govor životinja jer se i sama nalazi u svojevrsnoj ,zemlji

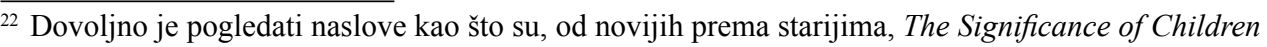
and Animals: Social Development and Our Connections with Other Species [Važnost djece i životinja: društveni razvoj i naše veze s drugim vrstama] (Meyers 2006), Why the Wild Things Are: Animals in the Lives of Children [Zašto postoje divlje stvari: životinje u dječjim životima] (Melson 2005), Children and Animals: Exploring the Roots of Kindness and Cruelty [Djeca $\mathrm{i}$ životinje: istraživanje korijena ljubaznosti i okrutnosti] (Ascione 2005) i „Cognitive Ethology: The Minds of Children and Animals" [Kognitivna etologija: dječja i životinjska svijest] (Ristau 1998) koji autorica započinje citatom iz Alice u Zemlji Čudesa; zatim tekstove kao što su „'A dog who I know quite well’: everyday relationships between children and animals“ [,Pas kojega jako dobro poznajem“: svakodnevni odnosi između djece i životinja] (Tipper 2011) i „Bringing Peace Home: A Feminist Philosophical Perspective on the Abuse of Women, Children, and Pet Animals" [Donošenje mira kući: feministička filozofska perspektiva na zlostavljanje žena, djece i životinja kućnih ljubimaca] (Adams 1994), da navedem samo nekoliko.

${ }^{23} \mathrm{Za}$ više detalja o razgovoru s djecom i osobitostima govora upućenoga djeci vidjeti Talking to Children: Language Input and Acquisition (Snow i Ferguson 1977), a posebno i tekst C. A. Fergusona „Talking to Children: Search for Universals“ (1978). 
čudesa“ - „međustupnju“ razvoja koji povezuje prirodni svijet i onaj civilizirani, svijet odraslih.

Analiza Sherry B. Ortner (1972) koja nastoji dati odgovor na pitanje univerzalne podređenosti žena muškarcima, a koju autorica primjećuje jednako u „primitivnim“ kao i razvijenim, zapadnim društvima, dotiče se i statusa djeteta $\mathrm{i}$ žene unutar društava diljem svijeta. U svojoj antropološkoj analizi subordinirane uloge žene, koja gotovo da je ,jedna od pravih univerzalija, svekulturna činjenica“ (Ortner 1972: 67), autorica postulira da iza te „univerzalije“ stoji tvrdoglavo i duboko ukorijenjeno kulturološko poimanje žene kao entiteta koji je zbog ženske tjelesnosti, određenih fizioloških procesa, rađanja i menstruacije „,bliži“ prirodi (dok je muškarac konceptualno bliži kulturnim tekovinama i produciranju kulture) ${ }^{24}$

Ako kulturu definiramo kao svojevrsnu nadogradnju koja čovjeka oslobađa ovisnosti o prirodi i prirodnome, onda je žena društveno ipak korak iza muškarca kojega njegova fiziologija ne sprječava da nesputano djeluje u domeni kulture i kulturnoga. ${ }^{25}$ Posljedica je te razlike različit psihološki okvir muškarca i žene: ženin psihološki okvir pod utjecajem je fiziologije njezina tijela i društvenoga položaja koji je, kako tvrdi Ortner, univerzalno ipak podređen u odnosu na muškarca, iako je raznovrstan, dinamičan i varijabilan u različitim kulturama i društvima.

Osim tih tjelesnih (prirodnih) karakteristika, za približavanje prirodi ${ }^{26}$ bitan je i odnos žena s djecom jer su i djeca, dok ne prođu proces „socijalizacije“, bliža prirodi nego onomu kulturnomu te se, kao i žene, kulturno percipiraju kao dio prirode (Ortner 172: 69-70):

${ }^{24}$ Navedeni je članak, „Is Female to Male as Nature Is to Culture?“ prvi feminističkoantropološki rad ove autorice koji je snažno odjeknuo u akademskim krugovima 70-ih godina prošloga stoljeća. Iako je njezin čuveni argument o tome da su muškarci aktivni sudionici u stvaranju kulture, a žene, iako također u tome sudjeluju, bliže konceptu prirode zbog osobitosti ženskoga tijela i njegovih funkcija, otada doživio kritike i opovrgavanja, jer se antropološki fokus s univerzalija pomaknuo na kulturne osobitosti svakoga društva, naroda i etničke skupine, ostao je važan primjer primjene koncepta binarnih opozicija (Levi-Strauss) kako bi se uspjeli objasniti određeni kulturni fenomeni, a potom i riješiti na praktičan način (promjenom političkoga i društvenoga uređenja koja bi omogućila ravnopravan odnos muškaraca i žena).

${ }^{25} \mathrm{O}$ kulturnim stavovima prema ženama, koji karikiraju pa čak i diskriminiraju ženu zbog njezine osobite fiziologije, svjedoči i sveprisutni vic o predmenstrualnome sindromu (PMS-u) koji se sastoji $\mathrm{u}$ tome da je $\mathrm{u}$ tome razdoblju žene navodno najbolje izbjegavati jer postaju psihički i emocionalno neuračunljive zbog hormonalnih promjena koje se događaju u njihovu tijelu svakoga mjeseca. I ta je anegdotalna situacija, diskriminatorna i seksistička u svojoj biti, samo jedan od pokazatelja duboko utkanoga kulturnoga stava o tome da je žena „rob“ svojega tijela i njegove fiziologije.

${ }^{26}$ Kultno djelo Sherry B. Ortner utjecalo je na stvaranje ekofeminističkih ideja o snažnijoj povezanosti žena s prirodom, većoj sklonosti žena okolišnim pokretima i brizi za okoliš i sva živa bića, ali i onih koje žene približavaju drugim životinjama u kontekstu eksploatacije patrijarhalnoga režima. Danas su takve konstrukcije podvrgnute kritičkomu promišljanju, za što su dobri primjeri članci „Earth Mother Myths and Other Ecofeminist Fables“ [Zemlja majka i ostale ekofeminističke basne] (Leach 2007) i „Gender Myths and Feminist Fables“ [Mitovi o rodu i feminističke basne] (Cornwall, Harrison i Whitehead 2007). 
Novorođenčad jedva da je ljudska i sasvim je animalizirana; poput životinja ni novorođenčad nije sposobna uspravno hodati, nekontrolirano obavlja nuždu, ne govori. Čak i malo starija djeca još uvijek nisu potpuno pod utjecajem kulture. Još uvijek ne razumiju društvene dužnosti, odgovornosti i moral; njihov je vokabular ograničen, kao i raspon naučenih vještina. Pokazuje se da je mnogim kulturnim praksama implicitno prepoznavanje povezanosti djece i prirode.

Začetke takva razmišljanja moguće je slijediti do viktorijanskoga doba koje, osim što je osobito po odvajanju i definiranju književnosti namijenjene isključivo djeci, ${ }^{27}$ također postaje razdobljem važnih znanstvenih hipoteza i teorija - poput one Darwinove o evoluciji. U sustavu viktorijanske znanosti dijete je zauzimalo razvojni, evolucijski stupanj između životinja i čovjeka. U časopisu Mind objavljena su dva članka koja odlično ilustriraju taj status djeteta, barem unutar znanstvenoga diskursa (usp. Cosslett 2002). Naime, 1877. godine objavljen je članak Hippolytea Tainea „The Acquisition of Language by Children“ [Kako djeca usvajaju jezik], a u sljedećemu je broju objavljen tekst Charlesa Darwina „Biographical Sketch of an Infant" [Biografska skica novorođenčeta]. Kao što prenosi Cosslett, u tim se člancima o razvoju djece i o načinu na koji usvajaju i uvježbavaju govor raspravlja uspoređujući ih sa životinjama, ali i s primitivnim pripadnicima egzotičnih plemena koja se $u$ to vrijeme otkrivaju $u$ raznim dijelovima svijeta. Za njihove autore (Taine citiran prema Cosslett 2002: 6):

[...] dijete predstavlja u prolaznome stanju prirodna obilježja koja se u fiksnome obliku nalaze u primitivnim društvima, slično kao što ljudski zametak predstavlja prolazno stanje fizičkih obilježja koja se u fiksnome stanju nalaze u vrstama inferiornih životinja.

Ideja o tome da djeca mogu razumjeti govor drugih životinja, kao i fantastični scenariji u kojima je sasvim normalno djeci plasirati animirane filmove i priče $u$ kojima životinje razgovaraju, svjedoče o kulturnome konceptu unutar kojega entitet djeteta još uvijek stoji na razmeđi imaginacije i realnoga svijeta, prirode i biološke određenosti i kulture i kulturnoga nadilaženja naših bioloških „ograničenja“. Jednako kao što svi odrasli znaju da životinje ne mogu govoriti, znaju i da djeca ne mogu i ne znaju govoriti kad se rode. U zamišljenome prostoru u kojemu djeca tek moraju svladati zahtjeve i kulturne kodove i pravila ponašanja, govora, svjetonazora i ideologija kulture i društva u kojemu odrastaju, moguće je prelaženje granica koje su nedostupne odraslima.

${ }^{27} \mathrm{O}$ razdoblju u kojemu se prvi puta zasebno spominje književnost za djecu te razdoblju u kojemu nastaje moderna, romantizirana ideja djetinjstva vidjeti Cosslett (2002). Iako su debate o tome kada se razvija ideja djetinjstva kao posebne razvojne faze u čovjekovu životu još uvijek aktivne i žive, Cosslett tvrdi da je dječja književnost koncept novijega datuma koji smješta na kraj osamnaestoga i početak devetnaestoga stoljeća, pritom se pozivajući na Gillian Avery (1975) i Hugha Cunninghama (1995). 
Autori poput Empsona (2006) koji su primijenili psihoanalitičku metodologiju u interpretaciji djela Aličine pustolovine u Zemlji Čudesa također primjećuju to da su životinje koje govore, kao i promjene relativne veličine, gotovo konvencionalan motiv u dječjim knjigama (za djecu priređene epizode iz Gulliverovih putovanja Jonathana Swifta, primjerice) pa stoga životinje (Empson 2006):

[...] očito nekako neposredno privlače dijete, ma kakve sofisticirane ideje bile na njih nagomilane. Djeca se osjećaju prirodno sa životinjama koje su zamišljene kao ljudi; životinja se može načiniti osjećajnom, a da djeci ne postavlja ozbiljne emocionalne zahtjeve, ne želi ih educirati, barem je nekonvencionalna u tome smislu da ne nameće svoje konvencije i ne mistificira prirodne procese. Stoga su životinje koje govore ovdje dječji svijet [...].

Iz takve je argumentacije jasno da o djetetu možemo razmišljati kao o „međustupnju“ razvoja koji se nalazi na razmeđi prirodnoga (divljega, životinjskoga) i kultiviranoga. Stoga postaje „logičnijim“ da upravo Alica, kao glavni akter vlastita dječjega svijeta, razumije životinje i može razgovarati s njima.

Kao što se može vidjeti iz prethodnoga tijeka izlaganja, dijete se najčešće percipira kao biće na zasebnome stupnju razvoja: iako u nekim svojim obrascima ponašanja nalikuje životinjama, to biće, za razliku od njih, u sebi ima potencijal postajanja punopravnim članom ljudskoga društva. Osim te kulturološke konstrukcije postoje i psihološke koje svjedoče o prediskustvenoj, imaginacijskoj vezi djece i životinjskih likova.

Kako to navodi Gilbert Durand, još je i švicarski psiholog Jean Piaget ustanovio neobičnu nadmoć zoomorfnih motiva koji prevladavaju u imaginaciji malene djece, a navodi i kako je slikovnih prikaza i simbola životinja najviše, daleko više od biljnih, a posebice antropomorfnih (1991: 65):

Od svih slika, doista, slike životinja najčešće su i najopćenitije. Može se reći da nam već od djetinjstva ništa nije bliže od prikaza životinja [...] plišani medvjed, mačak u čizmama, Mickey [...]. Polovina naslova dječjih knjiga posvećena je životinjama. U dječjim snovima što ih iznosi Piaget od tridesetak promatranja [...] devet se odnosi na snove o životinjama [...] djeca nikad nisu vidjela većinu životinja o kojima sanjaju [...]. To pokazuje kako teriomorfna orijentacija imaginacije tvori dubok sloj koji iskustvo nikad neće opovrgnuti $[\ldots]$.

Utvrđeno je, dakle, da je dječja imaginacija prepuna životinja i prije negoli započne proces socijalizacije i ,kultiviranja“, a u tome kontekstu ne čudi što je toliko didaktičkih sredstava i pomagala za učenje upravo zoomorfnoga i teriomorfnoga oblika. Debra Hawhee tvrdi da životinje obogaćuju naš jezik, ali i olakšavaju učenje jezične porabe jer postoje „mnoge karakteristike jezika koje je zbilja teško poučavati i tu onda na scenu stupaju prikazi životinja“" (2015). Osim što obitavaju u mašti i svijesti djece od najranije dobi, životinjski likovi sudjeluju u procesu 
učenja i spoznavanja svijeta, a mogu nas ponešto naučiti i o samoj upotrebi jezika i retoričkih figura (isto).

Priče o životinjama u suvremenome svijetu nemaju isključivo moralnoodgojnu ulogu kao primjerice basne u antičkoj Grčkoj, već i zabavljačku: u maniri satire „progovaraju“ o ljudskome svijetu, alegorijski o politici i religijama i karnevalski izvrću ustaljene konvencije i hijerarhije (usp. Blount 1974). Kako se mijenjala uloga priče o životinjama, mijenjao se i naš odnos prema njima, a ta su dva procesa zasigurno u međusobnoj povezanosti.

U razvijenim zapadnim društvima odnos čovjeka i životinje sve je manje neposredan, a sve više umjetan i simbolički, o čemu svjedoče brojni zoovrtovi, dokumentarni filmovi i antropomorfizirani prikazi drugih životinja, no unatoč tomu (Hawhee 2015):

[ž]ivotinjske metafore i primjeri ostaju snažnim komunikacijskim sredstvom. Iako nitko nije proveo iscrpno istraživanje o tome, čini se da su životinje korisne u svim jezicima. Detalji se možda razlikuju - u različitim kulturama možda je naglašen neki drugi životinjski aspekt - ali teško je zamisliti kakav bi jezik bio bez njih.

\section{Umjesto zaključka: ni cenzura nije jednostavna kao što se ponekad čini}

Iako je uglavnom nepoznata, nedovoljno istražena i slabo raspravljena, zabrana tiskanja, distribuiranja i čitanja djela Aličine pustolovine u Zemlji Čudesa dovodi nas u kompleksno i zamršeno polje u kojemu se prepliću priroda i kultura, političke ideologije, politički folklor i ontološko poimanje živoga svijeta, a koji su bili karakteristični za Kinu sredinom 20. stoljeća. ${ }^{28}$

Unatoč oscilacijama koje su u filozofiji prirode prisutne u svim društvima i narodima, razdoblje Kulturne revolucije u Kini označilo je pustošenje i „brisanje“ životinja, odnosno njezinih određenih vrsta: tigra, riječnoga dupina, slona, iz zbiljskih okoliša i iz svijeta animiranoga filma.

Politička ideologija pokoravanja divlje prirode uzrokovala je eksploataciju prirodnih resursa koja je u nekim slučajevima gotovo završila ekološkim katastrofama (nestancima čitavih vrsta), ali i promjenu u poimanju drugih životinja i njihova položaja u odnosu na čovjeka. Od ontološkoga jedinstva u vrijeme predbudističke Kine do jaza koji je odvojio ljude od životinja i uzrokovao ideje ekskluzivnih ljudskih karakteristika i artefakata - kao što su jezik i govor -

${ }^{28}$ Nažalost, usprkos opsežnim istraživanjima nije bilo moguće utvrditi je li zabrana ikada službeno ukinuta. No poznato je da se danas Alica čita. Zongxin Feng navodi da postoji 250 različitih prijevoda Alice na kineski od prvoga prijevoda 1922. do 2013. godine. Alicu je prevodilo više od 170 prevoditelja jer uz sto sedamdeset jednoga poznatoga prevoditelja postoji još petnaest skupnih 
posljedično su utjecali na recepciju književnoga djela Aličine pustolovine u Zemlji Čudesa.

Lewis Carroll vjerojatno nije na umu imao reperkusije feminističkoga iščitavanja svojega dječjega romana, diskurs binarnih opozicija ni raznih antropoloških „stupnjevitih trojstava“ kojima se mogu prikazivati hijerarhije živoga svijeta. Unatoč tomu, možemo i u tome svjetlu protumačiti Aličinu buntovnu ulogu i njezine sposobnosti da u posljednjoj dječjoj pustolovini prije stasanja u odraslu pripadnicu ljudske vrste, u duhu književnoga nonsensa, propita društvene norme i konvencije „svijeta odraslih“. Ima li boljega načina od razgovora s drugim životinjama za propitivanje društvene konvencije definicije govora kao ekskluzivno ljudske karakteristike?

Nakon svojevrsnoga obreda inicijacije i liminalnoga okruženja neobičnoga svijeta u kojemu se stvari povećavaju i smanjuju, a životinje govore, možemo li pretpostaviti da je Alica zaboravila kako se razgovara s drugim životinjama, kad je odrasla?

Empson (2006: 50 - 51) smatra da se odgovor na to pitanje krije na samome kraju djela:

[...] trijumfalni završetak 'zemlje čuda' jest da je [Alica] prerasla svoje fantazije pa si napokon može dopustiti da se probudi i prezre ih. [Roman] Alica s onu stranu ogledala manje je proizvod sna, manje je usmjeren na djetetovu situaciju, i (kad započne) manje je ispunjen promjenom veličine; ali ima jednak kraj; dadilja se stisnula u mačića kad je Alica narasla iz pješaka u kraljicu i može je tresti. Obje te [preobrazbe] očito predstavljaju odrastanje, a ipak su dijelom pobuna protiv ponašanja [poput] odraslih; postoji jednaka ambivalentnost kao i ona o životinjama koje govore.

Na temelju svega izloženoga možemo zaključiti da je dječja povezanost s drugim životinjama osobitost dječjega svijeta, faza koja se izgubi prilikom „socijaliziranja“ i punopravnoga stupanja u svijet odraslih. Ili barem tako nalažu društvene norme.

Kinesko je društvo u vremenima kad je general Ho Chien zabranio tiskanje i distribuciju knjige Aličine pustolovine u Zemlji Čudesa proživljavalo korjenite

prijevoda i pedeset izdanja čiji su prevoditelji nepoznati ili anonimni (Feng 2015: 187). Prvi je Alicu preveo Y. R. Chao, a taj je prijevod ,odigrao važnu ulogu u razvoju dječje književnosti u kontinentalnoj Kini“ (195). Međutim, kao što Feng bilježi u nastavku: „Gotovo trideset godina između 1950. i 1979., za vrijeme dok je sedamnaest izdanja Alice bilo tiskano ili pretisnuto u Tajvanu i Hong Kongu, ni jedno se jedino izdanje nije pojavilo na teritoriju Kine, iako su postojali pokušaji ranih 1960-ih godina [...]. Ubrzo nakon što su počele pripreme, urednici i književni učenjaci uključeni u taj projekt shvatili su da bi Alica samo stručnjacima mogla poslužiti kao predmet ozbiljna proučavanja, a da bi ju kineskoj djeci bilo vrlo teško čitati. Tek su se u ranim 1980-im godinama pojavili novi napori da se Alica prevede te su drugi nakladnici objavili četiri prijevoda (uključujući i jedno kombinirano izdanje s Alicom iza zrcala) u kontinentalnoj Kini 1981. godine“"(195-196). 
društvene, ekonomske i političke promjene koje su se odrazile na odnos ljudi prema prirodi i drugim životinjama. Komunistička ideologija utjecala je na razdvajanje ontološkoga jedinstva između svih živih bića i potaknula eksploatatorski stav prema prirodnim resursima: pitome i domaće životinje koje su mogle služiti čovjeku uzgajane su, dok su divlje životinje nemilice uništavane. Ta je politička opredijeljenost, prešavši u svjetonazorski stav, stvorila neprijateljsku klimu prema neukroćenoj prirodi i divljim životinjama, zbog čega je izjednačavanje između ljudi i životinja na bilo kojoj razini bilo izrazito nepoželjno. S obzirom na to da je govor jedna od utvrda ljudske osobitosti i superiornosti nad ostalim živim bićima koji je prisutan i u današnje vrijeme, ideja o tome da ga dijelimo s drugim životinjama u tome je kontekstu neprivlačna, pa čak i uvredljiva.

Propagandni animirani filmovi koji su nastali tijekom Kulturne revolucije prikazuju djecu kao borce koji služe političkomu sustavu, a umjesto poučnih i maštovitih priča servira im se ideološka dogma. U razdoblju velikih političkih, ekonomskih i društvenih turbulencija, kao u Kini u prvoj polovici 20. stoljeća, djeca su već zarana politički „mobilizirana“ čime im je uskraćeno pravo na bezbrižno djetinjstvo i slobodnu imaginaciju koja često uključuje osjećaj bliskosti s drugim životinjama, kao i ideju da s njima mogu razgovarati.

Zabrana Aličinih pustolovina u Zemlji Čudesa odraz je vladajuće ideologije i pripadajućih joj prioriteta u tadašnjoj Kini: pokoriti i eksploatirati prirodne resurse, druge životinje i ljudsku snagu s ciljem ekonomskoga razvoja. Iako je utjecaj politike Velikoga skoka naprijed na prirodu i životinjske vrste dobro istražen, utjecaj cenzuriranja i uklanjanja prikaza drugih životinja i ostalih fantastičnih motiva (poput razgovora sa životinjama) na dječji svijet i djetinjstvo još je uvijek otvorena tema.

\section{Popis literature}

Adams J., Carole. 1994. „Bringing Peace Home: A Feminist Philosophical Perspective on the Abuse of Women, Children, and Pet Animals“. Hypatia: Feminism and Peace 9 (2): 63-84.

Ascione, R. Frank. 2005. Children and Animals: Exploring the Roots of Kindness and Cruelty. Lafayette, Indiana: Purdue University Press.

Avery, Gillian. 1975. Childhood's Pattern: A study of the Heroes and Heroines of Children's Fiction, 1770-1950. London: Hodder \& Stoughton.

Berger, John. 2009. Why Look at Animals?. London: Penguin Books.

Blount, Margaret. 1974. Animal Land: The Creatures of Children's Fiction. London: Hutchinson.

Carroll, Lewis. 2004. Aličine pustolovine u Zemlji [Č]udesa. U Alica u Zemlji [Č]udesa i Iza zrcala. Preveo Antun Šoljan, 7-137. Zagreb: Školska knjiga. 
China Culture. 2008. „Chinese Animation Shows World it Has Midas Touch“. China Culture.org. <http://www1.chinaculture.org/library/2008-01/18/content_75374.htm> (pristup 19. studenoga 2015.).

Coggins, Chris. 2003. The Tiger and the Pangolin: Nature, Culture, and Conservation in China. Honolulu: University of Hawaii Press.

Cornwall, Andrea, Elizabeth Harrison i Ann Whitehead. 2007. „Gender Myths and Feminist Fables: The Struggle for Interpretive Power in Gender and Development". Development and Change 38 (1): 1-20.

Cosslett, Tess. 2002. „Child's Place in Nature: Talking Animals in Victorian Children's Fiction“. Nineteenth-Century Contexts: An Interdisciplinary Journal 23 (4): 475-495.

Cunningham, Hugh. 1995. Children and Childhood in Western Society Since 1500. London: Longman.

Derrida, Jaques [Žak Derida]. 1990. Bela mitologija. Novi Sad: Bratstvo-Jedinstvo.

Dunayer, Joan. 2009. Specizam: diskriminacija na osnovi vrste. Zagreb: Institut za etnologiju i folkloristiku, Čakovec: Dvostruka Duga.

Durand, Gilbert. 1991. Antropološke strukture imaginarnog. Zagreb: August Cesarec.

Elvin, Mark. 2006. The Retreat of the Elephants: An Environmental History of China. New Haven i London: Yale University Press.

Elvin, Mark. 2010. „The Environmental Impasse of the Late Imperial China“. U China's Rise in Historical Perspective, ur. Brantly Womack, 151-170. Lanham, MD: Rowman and Littlefield.

Empson, William. 2006.,Alice in Wonderland: The Child as Swain“. ULewis Carroll's Alice's Adventures in Wonderland: Modern Critical Interpretations, ur. Harold Bloom, 39-67. New York: Chelsea House Publishing. Bloom's Literary Reference Online. Facts On File, Inc. $<$ http://www.fofweb.com/activelink2.asp?ItemID=WE54\&SID=5\&iPin= MCIA AIW01\&SingleRecord $=$ True $>$ (pristup 20. travnja 2015.).

Feng, Zongxin. 2015. „Alice in Chinese Translation“. U Alice in a World of Wonderlands: The Translations of Lewis Carroll's Masterpiece. Volume One: Essays, ur. Jon A. Lindseth i Alan Tannenbaum, 187-198. New Castle, Delaware: Oak Knoll Press.

Ferguson, Charles A. 1978. „,Talking to Children: A Search for Universals“. U Universals of Human Language: Method \& Theory, Joseph Harold Greenberg, ur. Charles Albert Ferguson i Edith A. Moravcsik, 203-224. Stanford, California: Stanford University Press.

Giesen, Rolf. 2015. Chinese Animation: A History and Filmography, 1922-2012. Jefferson, NC: McFarland.

Hawhee, Debra. 2015. „Animals Enliven Human Language”. Razgovarala Cherie Winner. Phys.org. <http://phys.org/news/2015-04-animals-enliven-human-language.html> (pristup 27. travnja 2015.).

Jurić, Hrvoje. 2001. „Peter Singer-između Zagreba i Beograda“. Reč: časopis za književnost i kulturu i društvena pitanja 61 (7): 141-154.

Khasawneh, Hana. 2010. The Poetics of Literary Nonsense: Victorian Nonsense and its Resurgence in The Irish Modernist Literature. Saarbrücken: VDM Verlag.

Knight, John, ur. 2004. Wildlife in Asia. Cultural Perspectives. London: Routledge Courzon. Leach, Edmund [Lič, Edmund]. 1982. Klod Levi Stros. Beograd: Prosveta.

Leach, Melissa. 2007. „Earth Mother Myths and Other Ecofeminist Fables: How a Strategic Notion Rose and Fell“. Development and Change 38 (1): 67-85.

Lecercle, Jean-Jacques. 1994. Philosophy of Nonsense: The Intuitions of Victorian Nonsense Literature. London and New York: Routledge. 
Marks, Robert B. 2004. Tigers, Rice, Silk, and Silt: Environment and Ecology in Late Imperial South China. Cambridge: University of Cambridge Press.

Melson F., Gail. 2005. Why the Wild Things Are: Animals in the Lives of Children. Cambridge: Harvard Univesity Press.

Meyers, Gene. 2006. The Significance of Children and Animals: Social Development and Our Connections with Other Species. West Lafayette, Indiana: Purdue University Press.

Nodelman, Perry. 2004. „Picture Books and Illustration”. U International Encyclopedia of Children's Literature. Volume I, 2. izd., ur. Peter Hunt, 154-165. London and New York: Routledge.

Noske, Barbara. 1997. Beyond Boundaries: Humans and Animals. Montreal/New York/ London: Black Rose Books.

Ortner B., Sherry. 1972. „Is Female to Male as Nature Is to Culture?“. Feminist Studies 1 (2): 5-31.

Ristau A., Caroline. 1998. „Cognitive Ethology: The Minds of Children and Animals“. U The Evolution of Mind, ur. D. Dennise Cummings i Allen Collin, 107-161. New York: Oxford University Press.

Rojas, Carlos i Eileen Chow, ur. 2013. The Oxford Handbook of Chinese Cinemas. Oxford: Oxford University Press.

Shapiro, Judith. 2001. Mao's War Against Nature: Politics and the Environment in Revolutionary China. Cambridge: Cambridge University Press.

Simoniti, Barbara. 1997. Nonsens. Ljubljana: Založba Karantanija.

Singer, Peter. 1998. Oslobođenje životinja. Zagreb: Ibis Grafika.

Skok, Petar. 1988. Etimologijski rječnik hrvatskoga ili srpskoga jezika. Zagreb: JAZU.

Snow, Catherine E. i Charles A. Ferguson. 1977. Talking to Children: Language Input and Acquisition. Cambridge: Cambridge University Press.

Sova B., Dawn. 2006. Banned Books: Literature Suppressed on Social Grounds. New York: Facts on File.

Sterckx, Roel. 2000. „Transfroming the Beast: Animals and Music in Early China“. T'oungpao 86: 1-46. Intranet.ames.cam.co.uk. <http://intranet.ames.cam.ac.uk/ rs10009/ Transforming\%20the\%20Beasts.pdf $>$ (pristup 15. studenoga 2015.).

Sterckx, Roel. 2002. The Animal and the Deamon in Early China. Albany: SUNY Press.

Sterckx, Roel. 2004. „Attitudes Toward Wildlife and the Hunt in Pre-Buddhist China“. U Wildlife in Asia: Cultural Perspectives, ur. John Knight, 15-35. London i New York: Courzon / Routledge.

Sterckx, Roel. 2005. „Animal Classification in Ancient China“. EASTM (East Asian Science, Technology, and Medicine) 23: 26-53. Intranet.ames.cam.ac.uk. $<$ http://intranet.ames. cam.ac.uk/ rs 10009/Sterckx\%20EASTM.pdf $>$ (pristup 15. studenog 2015.).

Sterckx, Roel. 2007. „Searching for Spirit: Shen and Sacrifice in Warring States and Han Philosophy and Ritual“". Extrême-Orient, Extrême-Occident 29: 23-54. Persee.fr. $<$ http://www.persee.fr/doc/oroc_0754-5010_2007_num_29_29_1083> (pristup 10. studenog 2015.).

Strachey, Edmund. 1888. „Nonsense as a Fine Art“. Quarterly Rewiev 167: 515-531. Nonsenselit.org. <http://www.nonsenselit.org/Lear/pdf/nonsense.pdf> (pristup 20. studenoga 2015.).

Struve, A. Lynn. 1993. Voices from the Ming-Qing Cataclysm: China in Tigers'Jaws. Yale University Press.

Tigges, Wim. 1988. An Anatomy of Literary Nonsense. Amsterdam: Rodopi. 
Tilson, Ronald i Ulysses Seal. 1987. Tigers of the World. The Biology, Biopolitics, Management and Conservation of an Endangered Species. New Jersey: Noyes Publication.

Tipper, Becky. 2011. „'A Dog Who I Know Quite Well’: Everyday Relationships between Children and Animals“. Children's Geographies 9 (2): 145-165. Academia.edu. $<$ http://dx.doi.org/10.1080/14733285.2011.562378> (pristup 24. ožujka 2015.).

Turvey, Samuel. 2009. Witness to Extinction: How We Failed to Save the Yangtze River Dolphin. London: Oxford University Press.

World Public Library. 2015. „History of Chinese Animation“. Project Gutenberg SelfPublishing Press. <http://self.gutenberg.org/article/whebn0008578294/history\%20of $\%$ 20chinese \%20animation> (pristup 19. studenoga 2015.).

Yan Du, Daisy. 2012. On the Move: The Trans/national Animated Film in 1940s-1970s China. Doktorska disertacija. Wisconsin: University of Wisconsin-Madison.

Yan Du, Daisy. 2016. (U tisku). „The Dis/appearance of Animals in Animated Film during the Chinese Cultural Revolution, 1966-1976“. Positions: Asia Critique 24 (2). Sažetak dostupan na mrežnome mjestu Hong Kong University of Science and Technology Institutional Repository <http://repository.ust.hk/ir/Record/1783.1-60845> (pristup 20. studenoga 2015.).

Zeman, Zdenko i Marija Geiger. 2007. „Karizmatična fauna u službi konstruiranja lokalnog identiteta“. Društvena istraživanja 16 (6): 1055-1079.

\section{Lidija Bernardić}

University of Zagreb, Croatia

Zagreb Universität, Kroatien

\section{Alice in a Land of Censorship: The Children's World as a Place Where People Talk to Animals}

This paper offers a possible explanation of the political ban on distributing and reading Alice in Wonderland, which in China's Hunan province came into force in 1931. The relations between people (especially rulers and other functionaries) and other animals and the element of communist ideology and its view of nature provide a key to understanding the proclaimed ideological and political unsuitability of this literary work. After interpreting the reasons why "giving language to animals" might be viewed as a subversive act at the time of the empowerment of communist rule in China, I interpose Alice within a feminist anthropological concept of "proximity to nature" to explain why girls (Alice), in their own children's worlds, can understand other animals.

Keywords: animals, children's world, censorship, communist ideology, feminist anthropology, speech

\section{Alice im Land der Zensur: Die Kinderwelt als Ort des Gespräches mit Tieren}

Im Beitrag wird die Frage erörtert, weshalb man 1931 in der chinesischen Provinz Hunan das Lesen und den Erwerb von Alice im Wunderland verboten hatte. Die Beziehung 
der Menschen (insbesondere der Herrscher) zu anderen Tieren sowie das Verhältnis der kommunistischen Ideologie zur Natur könnten einen Schlüssel dafür liefern. Zuerst wird erklärt, warum zur Zeit des Aufstiegs der kommunistischen Herrschaft in China die Tatsache, dass man in einem literarischen Werk Tiere sprechen lässt, als subversiv empfunden wurde. Danach wird anhand der Positionierung der Kinder in den Zwischenraum zwischen der Natur (Tiere) und den Erwachsenen sowie des feministischen Lesens der Frau als eines der Natur näherstehenden Wesens die Erklärung dafür dargeboten, warum das Mädchen Alice in seiner Kinderwelt andere Tiere verstehen kann.

Schlüsselwörter: Kinderwelt, Zensur, feministische Anthropologie, Rede, kommunistische Ideologie, Tiere 


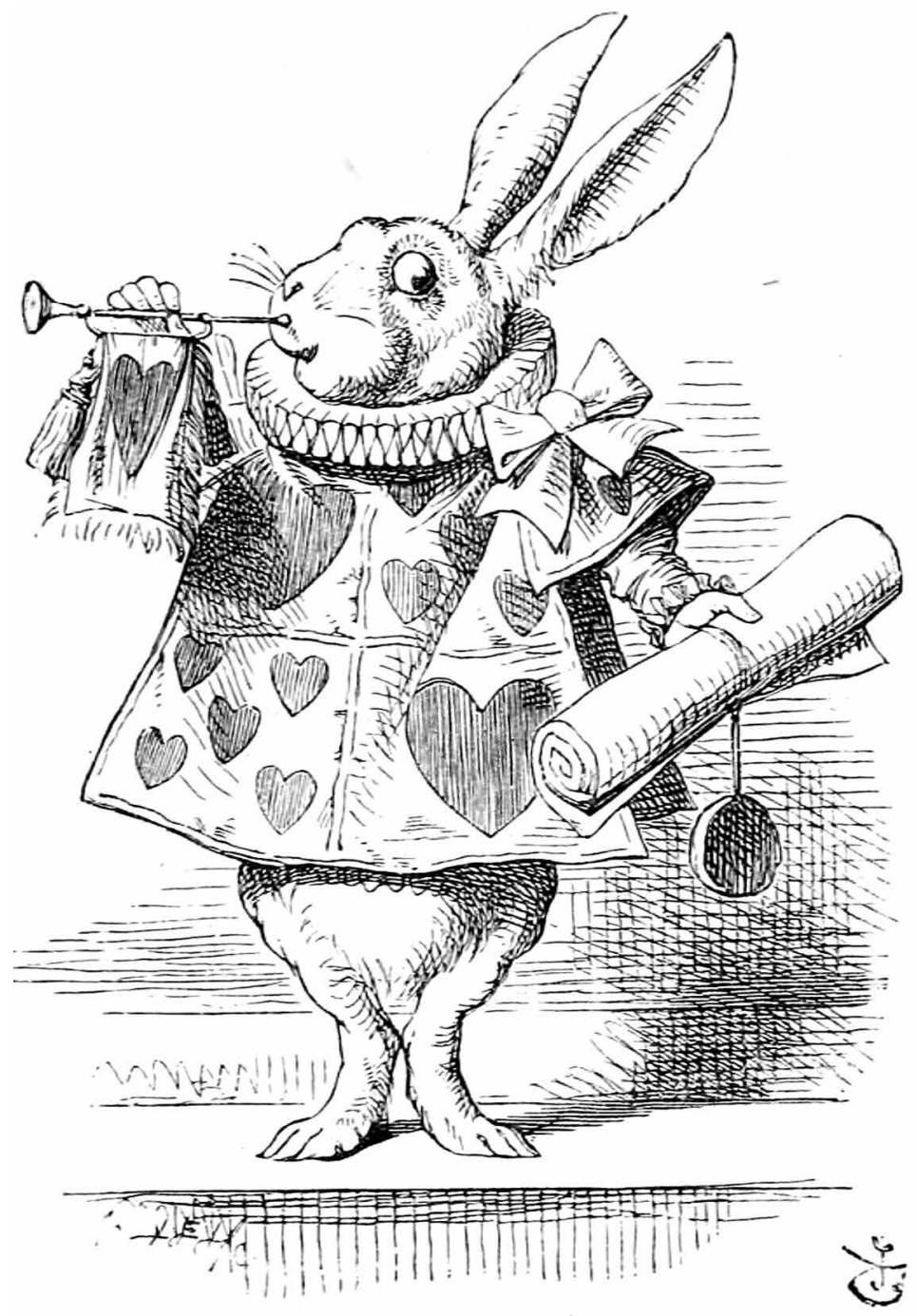

The White Rabbit blows three times before reading the accusation. Sir John Tenniel. Alice's Adventures in Wonderland, 1865, p. 166.

Bijeli Zec trubi tri puta prije čitanja optužnice. Sir John Tenniel. Alice's Adventures in Wonderland, 1865., str. 166. 